\title{
Evaluation of the Effectiveness of the Use of Papaya Fruit Latex in Making Herbal Medicated Multinutrition Block as a Local Goat Feed Supplement
}

\author{
Retno Iswarin Pujaningsih, Baginda Iskandar Moeda Tampoebolon, Widiyanto and Dian Wahju Harjanti \\ Department of Animal Husbandry, Faculty of Animal and Agriculture Science, University of Diponegoro, \\ Jl. Prof. Soedarto, Tembalang, Semarang, 50275 Central Java, Indonesia \\ *Corresponding author e-mail: retno.marwoto@gmail.com
}

\begin{abstract}
The use of papaya latex formulated with nitrogen supplementation and minerals in the form of multinutrition blocks that can pass through the rumen is expected to improve nutritional quality and feed digestibility. This study aims to evaluate the effectiveness of the use of fermented rice straw, papaya fruit latex and blood clamshell flour as a main raw material in the manufacture of multinutrition blocks plus herbal anthelmintic medicine (papaya fruit latex) on physical quality (texture, color, aroma, hardness), chemical quality (proximate composition and mineral content of $\mathrm{Ca}, \mathrm{P}, \mathrm{Mg}, \mathrm{Cu}, \mathrm{Zn}$ ). Microbiological tests were carried out on total bacteria, Salmonella and Escherichia coli. The research design used was a completely randomized design with 4 treatment levels of papaya fruit administration and 4 replications. Data is processed statistically using ANOVA. The results of organoleptic physical quality analysis showed significant differences in the texture of the product given the highest papaya latex $(0.007 \mathrm{ml} / \mathrm{kg})$. Chemical analysis of the product showed a quantitative increase in protein, although statistically the treatment did not show any significant differences. The results of the analysis of the microbiological quality of the product quantitatively showed that the resulting multinutrition block herbs were not contaminated with negative bacteria. It was concluded that multinutrition block herbs can be given to livestock as supplementary feed.
\end{abstract}

Key words: papaya latex, multinutrition blocks, anthelmintic herbal, local goat

Abstrak. Pemberian getah pepaya yang diformulasikan dengan pemberian suplementasi nitrogen dan mineral dalam bentuk multinutrisi blok yang dapat melewati rumen diharapkan mampu meningkatkan kualitas nutrisi dan kecernaan pakan. Penelitian ini bertujuan untuk mengevaluasi efektifitas penggunaan jerami padi yang difermentasi, getah buah pepaya serta tepung cangkang kerang darah sebagai bahan baku andalan pada pembuatan multinutrisi blok plus anthelmintic medicine herbal (getah buah pepaya) terhadap kualitas fisik (tekstur, warna, aroma, kekerasan), kualitas kimia (komposisi proksimat dan kandungan mineral $\mathrm{Ca}, \mathrm{P}, \mathrm{Mg}, \mathrm{Cu}$, Zn). Uji mikrobiologis dilakukan terhadap total bakteri, Salmonella dan Escherischia coli. Desain penelitian yang digunakan adalah rancangan acak lengkap dengan 4 perlakuan level pemberian getah buah pepaya dan 4 ulangan. Data diolah secara statistik menggunakan anova. Hasil analisis kualitas fisik secara organoleptik menunjukkan perbedaan yang nyata pada tekstur produk yang diberi getah papaya tertinggi $(0,007 \mathrm{ml} / \mathrm{kg})$. Analisis produk secara kimiawi menunjukkan adanya peningkatan protein secara kuantitatif meskipun secara statistik perlakuan tidak menunjukkan perbedaan yang nyata. Hasil analisis kualitas mikrobiologi produk secara kuantitatif menunjukkan bahwa herbal multinutrisi blok yang dihasilkan tidak tercemar bakteri negatif. Disimpulkan bahwa herbal multinutrisi blok dapat diberikan kepada ternak sebagai pakan pelengkap.

Kata kunci: getah pepaya, multinutrisi blok, anthelmintic herbal, kambing lokal

\section{Introduction}

The unbalanced effects of nutrient supply on ruminants include low productivity, susceptibility to disease infestations that cause high mortality rates. Nematode worm infestation in many cases reported by
Suhardono et al., (2012) occurs in young goats during growth. According to Malesi (2010) worms that commonly interfere with the health of goats and sheep are from the Nematode class, and the most dangerous type is Haemonchus contortus (tapeworm) which lives in the 
abomasum and lives as a blood sucking with infestation rates according to Lastuti et al., (2006 ) can reach $80 \%$. This worm will lead to death in livestock, the growth of livestock will be disrupted to cause reproductive problems (Malesi, 2010)

Goats that show symptoms of intestinal worms can be treated with traditional medicine or with manufacturing drugs. Traditional medicines such as papaya latex or papaya leaf juice are cheaper, easier to obtain, can be done by farmers, and have no harmful side effects compared to manufacturer's drugs. According to Permana (2013) papaya (Carica papaya L.) is a plant that almost all parts of the plant can be used for various purposes. Almost all parts of this plant from the roots, leaves, sap, to the seeds, have been empirically used as anthelmintics. Anthelmintic is an ingredient used to destroy worms in the digestive tract of goats.

Increasing the productivity of ruminants through the provision of practical nutrition must be developed so that it is easily applied by smallholder farmers. This includes feed supplementation using block multinutritions containing minerals according to the standard requirements of goats and microbial growth factors to increase feed digestibility. In this study, multinutrition blocks were given additional herbal anthelmintic to overcome nematode worm infestations which can interfere with the growth of livestock.

\section{Materials and Methods}

Providing multinutrition block herbs was done by using raw materials in the form of rice straw fermented with EM4, blood clam shells, young papaya sap, molasses, urea, bentonite, salt and lime. The main equipment used is mold blocks, grinders and pans to heat molasses.

\section{Providing herbal medicated multinutrition block}

Before being mixed with other raw materials, rice straw is fermented for 14 days with EM4 and rice bran, then dried and ground. Clamshell also needs to be grindered first before mixed together in the formulation. Multinutrition block herbal formulations showed on Table 1 . Molasses were heated for 10 minutes at $40^{\circ} \mathrm{C}$ then mixed with other raw materials. Papaya fruit latex is added according to research treatment. After homogeneous the mixture is weighed 600 grams each and formed using a 10 $\mathrm{cm}$ diameter pipe. Then after being solid and hardened, divided into 4 with the same weight. Each mixture is made 4 times for each treatment.

Table 1. Formulation of Herbal Medicated Multinutrition Block

\begin{tabular}{ll}
\hline Raw material & \% \\
\hline Molasses & 50 \\
Fermented rice straw & 30 \\
Salt & 3 \\
Clamshell & 6 \\
Urea & 4 \\
Bentonite & 7 \\
\hline
\end{tabular}

\section{Tapping papaya fruit latex}

To get young papaya latex, young papaya fruit is sliced as deep as a maximum of $2 \mathrm{~mm}$. Each fruit has a maximum of 4 slices with a distance of $2 \mathrm{~cm}$. Young papaya sap is collected for 2 hours every 3 days on the same fruit.

\section{Treatment}

The level of papaya fruit latex that ws given is T0: 0 ml / kg, T1: $0.003 \mathrm{ml} / \mathrm{kg}$, T2: $0.005 \mathrm{ml} / \mathrm{kg}$ and T3: $0.007 \mathrm{ml} / \mathrm{kg}$ for the treatment. Variables were measured organoleptically (texture, color, hardness and aroma), chemistry (proximate composition and minerals $\mathrm{Ca}, \mathrm{P}, \mathrm{Mg}$, $\mathrm{Cu}, \mathrm{Zn}$ ) and microbiology (total bacteria, Escherichia coli, Salmonella sp.). The research design used was a completely randomized design with 4 treatments and 4 replications. Data analysis using ANOVA.

\section{Results and Discussion}




\section{Physical quality test results}

The organoleptic block multinutrition quality test was carried out by 10 trained semi-panelists. Organoleptic test results are shown in Table 2.

Table 2. Physical quality test results of herbal medicated multinutrition block

\begin{tabular}{cclll}
\hline $\begin{array}{c}\text { Treatmen } \\
\mathbf{t}\end{array}$ & Colour & $\begin{array}{l}\text { Textur } \\
\mathbf{e}\end{array}$ & Aroma & $\begin{array}{l}\text { Hardn } \\
\text { esses }\end{array}$ \\
\hline T0 & 4 & $3.64^{\mathrm{a}}$ & 3.88 & $3.28^{\mathrm{a}}$ \\
T1 & 4 & $3.64^{\mathrm{a}}$ & 3.88 & $3.3^{\mathrm{a}}$ \\
T2 & 4 & $3.78^{\mathrm{a}}$ & 3.78 & $3.35^{\mathrm{a}}$ \\
T3 & 4 & $3.98^{\mathrm{b}}$ & 3.82 & $3.65^{\mathrm{b}}$ \\
\hline
\end{tabular}

Different superscripts in the same column show different treatments $(P<0.05)$

Notes: T0: without papaya latex, T1 with $0,003 \mathrm{ml} / \mathrm{kg}$ of papaya latex, $\mathrm{T} 2$ : with $0,005 \mathrm{ml} / \mathrm{kg}$ of papaya latex, T3: with $0,007 \mathrm{ml} / \mathrm{kg}$ of papaya latex

Based on Table 2 there are significant differences in texture and hardness of herbal medicated multinutrition block (T3) treatment compared to other treatments $(\mathrm{T} 0, \mathrm{~T} 1, \mathrm{~T} 2)$. The addition of $0.007 \mathrm{ml} / \mathrm{kg}$ of latex papaya is thought to cause a tighter texture and denser hardness than other treatments. Papaya latex is a white liquid that is sticky and released from plants that have laticifer or sap producers (Kusumadjaja and Dewi, 2005). Refer to Yusha'u et al., (2009) the milky juice of papaya (latex papaya) is used as chewing gum. The ability of papaya latex to bind the ingredients of the herbal medicated multinutrition block affects the texture and hardnesses to become more tight and dense.

The sensor of color and aroma has no significant difference since molasses becomes the dominant amount of herbal medicated multinutrition block. Molasses is responsible for the dark color of the product. Its dark color caused by the second boiling cycle of sugarcane (Kaushik et al., 2018)

\section{Chemical quality test results}

The proximate composition of multinutrition block herbs is shown in Table 3. From Table 3 it can be seen that the nutritional content of multinutrition herbs in the treatment blocks of $\mathrm{T} 1$ and $\mathrm{T} 2$ is quantitatively different from the percentage of protein content. While the other nutritional content is not significantly different. The fermentation process of rice straw using EM4 and fermented for 14 days can increase the crude protein content. During the fermentation process there is a change in structured carbohydrates and non-structural carbohydrates proven by the decrease in the content of crude fiber in fermented rice straw by $30.88 \%$ of crude fiber content of unfermented rice straw by $32.14 \%$ (Table 4). The addition of papaya fruit latex although not statistically significant, quantitatively tends to increase the protein content of the herbal multinutrition block. According to Rodrigues et al., (2009) papaya fruit latex contains about $30 \%$ of protease enzymes and $10 \%$ of other proteins.

Although the mineral content of rice straw is quite complete, in general it is relatively lower compared to the mineral content of grasses and legumes. Low quality feed which has a high content of fiber mostly contains very low minerals so that it becomes a limiting factor for microbial growth in the rumen such as $\mathrm{P}$ and $\mathrm{S}$ content. Therefore, it is necessary to add minerals to the livestock ration if rice straw is used as the main feed.

Mineral content in rice straw is used by microorganisms found in EM4 to help metabolize activity in digesting crude fiber. Stimulatory factors that significantly increase the value of substrate digestibility by stem bacteria $(P<0.05)$ when compared to controls are Fe; $\mathrm{Zn}$; Se; $\mathrm{Cu}$; $\mathrm{Co}, \mathrm{Mo}$, and $\mathrm{Mn}$. There are similarities and differences in effects between substances used in the activity of bacterial cocci and stems. $\mathrm{Zn} ; \mathrm{Co} ; \mathrm{Cu}$ and Mo increase the activity of bacterial cocci and stem (Thalib et al., 2000). In general, the mineral content of multinutrition herbal blocks in each treatment was not significantly different. 
Table 3. Proximate composition of herbal medicated multinutrition block

\begin{tabular}{llllll}
\hline \multirow{2}{*}{ Treatment } & $\begin{array}{l}\text { Dry } \\
\text { Matter }\end{array}$ & Ash & $\begin{array}{l}\text { Crude } \\
\text { fiber }\end{array}$ & $\begin{array}{l}\text { Crude } \\
\text { Fat }\end{array}$ & Protein \\
\hline T0 & 75.54 & 15.66 & 9.34 & 1.77 & 4.69 \\
T1 & 75.60 & 15.68 & 9.31 & 1.80 & 4.72 \\
T2 & 75.75 & 15.72 & 9.40 & 1.82 & 4.76 \\
T3 & 75.80 & 15.74 & 9.35 & 1.83 & 4.81 \\
\hline
\end{tabular}

Table 4. Nutrient content of rice straw

\begin{tabular}{llllll}
\hline Sample & $\begin{array}{l}\text { Dry } \\
\text { matter }\end{array}$ & Ash & $\begin{array}{l}\text { Crude } \\
\text { fiber }\end{array}$ & $\begin{array}{l}\text { Crude } \\
\text { fat }\end{array}$ & Protein \\
\hline & & & & & \\
RS & 84.22 & 22.25 & 32.14 & 3.32 & 5.31 \\
FRS & 79.11 & 21.34 & 30.88 & 2.41 & 7.72 \\
\hline
\end{tabular}

Note: RS: Rice straw, FRS: Fermented Rice Straw

Table 5. Herbal medicated multinutrition block mineral content

\begin{tabular}{llllll}
\hline Treatment & $\mathrm{Ca}$ & $\mathrm{P}$ & $\mathrm{Mg}$ & $\mathrm{Cu}$ & $\mathrm{Zn}$ \\
\hline T0 & 147.53 & 0.16 & 8.01 & 1.92 & 0.16 \\
$\mathrm{~T} 1$ & 147.80 & 0.16 & 8.15 & 1.95 & 0.16 \\
$\mathrm{~T} 2$ & 148.27 & 0.16 & 8.19 & 1.98 & 0.16 \\
$\mathrm{~T} 3$ & 148.11 & 0.17 & 8.21 & 2.00 & 0.17 \\
\hline
\end{tabular}

\section{Microbiological quality test results}

The addition of EM4 to the rice straw fermentation process affected the total number of multinutrition block bacteria (Table 6). In general no Escherichia coli and Salmonella sp bacteria were identified. on block multinutrition. The presence of flavonoids in papaya fruit latex which functions as antimicrobials plays a role in preventing the development of pathogenic bacteria (Kaushik et al., 2018)

Table 6. Total Bacteria, Gram Bacteria, Identification of Escherichia coli and Salmonella $s p$.

\begin{tabular}{lllll}
\hline Parameter & T0 & T1 & T2 & T3 \\
\hline Total Bakteri & $1,26 \times$ & $1,26 \times$ & $1,29 \times$ & $1,28 \times$ \\
(cfu/g) & $10^{4}$ & $10^{4}$ & $10^{4}$ & $10^{4}$
\end{tabular}

\begin{tabular}{|c|c|c|c|c|}
\hline \multicolumn{5}{|l|}{$\begin{array}{l}\text { Bakteri } \\
\text { Gram * }\end{array}$} \\
\hline E. coli ** & Negatif & Negatif & Negatif & Negatif \\
\hline $\begin{array}{l}\text { Salmonella } \\
\text { sp. ** }\end{array}$ & Negatif & Negatif & Negatif & Negatif \\
\hline Votes: $\begin{array}{r}{ }^{*}: \\
* *\end{array}$ & & & & \\
\hline
\end{tabular}

\section{Conclusions}

From the results of this work, it can be concluded that herbal medicated multinutrition block can be given to livestock as supplementary feed.

\section{Acknowledgement}

I would like to thank the Research and Community Service Institutions of UNDIP for the chance to have funding and support through my research. I would like to thank my teams for accepting nothing less than excellence from me. Last but not the least, I would like to thank my students and Mr. Julianto, the owner of the goat farm, for supporting me finishing this work.

\section{References}

Amin, M, S.D Hasan, O. Yanuarianto, M. Iqbal dan I.W Karda. 2016. Peningkatan Kualitas Jerami Padi Menggunakan Teknologi Amoniasi Fermentasi. Jurnal IImu dan Teknologi Peternakan Indonesia, Volume 2 (1): 96-103; Juni 2016 ISSN: 2460-6669

Babale D. M., Kibon A and Yahaya M. S. 2015. Performance and linear body measurements of Red Sokoto male goats on replacement levels of corn cobs for maize bran with cowpea husk basal diet. Net Journal of Agricultural Science. Vol. 3(2), pp.35-40, April 2015.ISSN: 2315-9766

Bakshi, M.P.S and Wadhwa, M. 2011. Nutritional status of dairy animals in different regions of Punjab State in India. Indian Journal of Animal Science 81: 52-58.

Bheekhee, H., B. Bulman, RK. Boodoo, R Rammuth, L. Heung, R Yeun, R Fakim and B. Dobee, 1999. Development and field evaluation of animal feed supplementation packages for improving meat and milk production in ruminant livestock using locally available feed resources. Livestock Research Department, Agricultural Research and 
Extension Unit, Food and Agricultural Research Council, Quatre Bomes, Mauritius, pp: 1-9.

Dinas Peternakan dan Kesehatan Hewan Provinsi Jawa Tengah. 2016. Sensus Hasil Pertanian Provinsi Jawa Tengah 2013. http://www.pertanian.go.id/dinakkeswan_jateng Fayomi, A., Ahmed, A., Musa, U., Salami-Shinaba, J.O., Ogedegbe, S.A and Akanni, K. 2014. Moringa Multi-Nutrient Blocks: Formulation, Production and Feeding Trial Under a Tropical Environment. International Journal of Science, Environment and Technology, Vol. 3, No 1, 2014, 67 - 84 ISSN 22783687

Garcia, L.O and J.I.R. Restrepo, 1995. Multinutrient Block Handbook (FAO Better Farming Series no. 45). Food and Agriculture Organization of United Nation, Rome.

Kaushik, A., S.Basu, V.S.Batra and M.Balakrishnan. 2018. Fractionation of sugarcane molasses distillery wastewater and evaluation of antioxidant and antimicrobial characteristics. Industrial Crops and Products. Volume 118: 73-80. https://doi.org/10.1016/j.indcrop.2018.03.040

Kusumadjaja, PA and R.P. Dewi. 2005. Determination of Optimum Condition of Papain Enzyme from Papaya Var Java. Indo. J. Chem., 2005, 5 (2), 147 151. https://doi.org/10.22146/ijc. 21822

Lukiwati, D.R dan R.I. Pujaningsih. 2014. Efek Sisa Pupuk Kandang Diperkaya Fosfat Alam terhadap Produksi Jagung Manis dan Jerami di Lahan Kering. Jurnal Lahan Suboptimal. 3(2): 152-160.

Lukiwati, D.R. dan R.I. Pujaningsih. 2015. Efek sisa pupuk kandang diperkaya fosfat alam dalam bentuk granular dan di inokulasi biodekomposer terhadap nutrisi jerami jagung manis di lahan kering. Jurnal Pastura,(terindeks DOAJ dan Google Schoolar). 4(2): 78-82.

McAllan, A.B. 1991. Optimizing the Use of Poor Quality Forage Feed Resources for Ruminant Production: Supplementation with Bypass Nutrients. In Proceeding of a Symposium : Isotope and Related Techniques in Animal Production and Health. Vienna, 15-19 April, 1991. Jointly organized by IAEA and FAO. pp.25-41

Mohammed, I.D, M. Baulube and A. Adeyinka. 2007. Multi-nutrient Blocks I: Formulation and Production under a Semi-arid Enviromuent of North East Nigeria. Journal of Biological Sciences 7 (2): 389-392. ISSN 1727-3048
Mubi, AA., Kibon, A and Mohammed, I.D. 2011. Effects of multinutrient blocks supplementation on the performance of grazing Yankaza sheep in the wet season of guinea savanna region of Nigeria. International Journal of Sustainable Agriculture 3: 103-06

Pujaningsih, R. I, Mukodiningsih, Sri, Pakpahan, Irjon. 2017. Cassava waste processing technology to support the provision of alternative feed on zero waste management system of livestock. Advanced Science Letters, Volume 23, Number 3, March 2017, pp. 2595-2597(3). American Scientific Publishers. DOI: https://doi.org/10.1166/asl.2017.8726

Rodrigues S.P., da Cunha M., Ventura J.A. and Fernandes P.M.B. 2009. Effects of the Papaya meleira virus on papaya latex structure and composition. Plant Cell Rep.28:861-871. doi: 10.1007/s00299-009-0673-7.

Simbolon, Nico, R.I. Pujaningsih dan S. Mukodiningsih. 2016. Pengaruh berbagai pengolahan kulit singkong terhadap kecernaan bahan kering dan bahan organik secara in vitro, protein kasar dan asam sianida. Jurnal Ilmu-IImu Peternakan 26 (1): 58 - 65

Sulistiyanto, B, S.Sumarsih, C.S Utama, R.I.Pujaningsih, C.I.Sutrisno. 2012. Effect of drying methods to the lactic acid bacteria of enriched cassava meals. Bul. Sintesis. Vol 16 (2). Hal : 23-26. Desember 2012

Suttle, N.F. 1991. Mineral supplementation of low quality roughage. In Proceeding of a Symposium : Isotope and Related Techniques in Animal Production and Health. Vienna, 15-19 April, 1991. Jointly organized by IAEA and FAO. pp.113-126.

Syahriani, Syahrir, M. Zain Mide, Rohmiyatul Islamiyati dan Ani Asrianie. 2015. Efektifitas Fermentasi Rumen thd Pakan Campuran Jerami Padi dan Biomassa Murbei dengan Penambahan Urea Mineral Molases Liquid. JITP Vol. 4 No. 1, Januari 2015

Tampoebolon, BIM, Z. Bachruddien, L.M. Yusiati dan S. Margino. 2013. Pengaruh Aplikasi Bakteri Lignoselulolitik Usus Rayap Terseleksi Pada Fermentasi Jerami Padi Terhadap Komposisi Serat. Jurnal Sintesis (Ilmu-ilmu Pertanian) Yayasan Dharma Agrika Semarang Volume 17, no 1. Juni. 
Van Soest, P.J. 1994. Nutritional Ecology of the Ruminant. 2nd Ed. Cornell Univ. Press. Ithaca and London.

Wadhwa, M and M.P.S. Bakshi. 2014. Nutritional evaluation of urea molasses multi-nutrient blocks containing agro-industrial wastes in buffaloes. Indian Journal of Animal Sciences 84 (5): 544-548.

Widiyanto, E. Kusumanti, M. Mulyono and S. Surahmanto. 2012. The Influence of Season and Topography on Manganese (Mn) Status of Grazing Java Thin-Tailed Sheep in the Agriculture Area in Mijen of Semarang-Central Java. Journal Of Indonesian Tropical Animal Agriculture. Vol 38, No 2 (2013). DOI: 10.14710/jitaa.38.2.131-138

Widiyanto, E. Pangestu, Surahmanto, V.D. Yunianto, B.I.M. Tampoebolon and B.W.H.E. Prasetiyono. 2015a. Effect of Mineral Supplementation and Introduction of Setaria sphacelata Grass and
Gliricidia sepium Legume on Productivity of Kacang Goat at Serang River Basin Upland Area, Central Java, Indonesia. Pakistan Journal of Nutrition. Volume: 14(8) pp. 440-446. DOI: 10.3923/pjn.2015.440.446

Widiyanto, Sumarsono, Sudjatmogo, B.W.H.E Prasetiyono, A.Setiadi and Surahmanto. 2015b. lodine Mineral Status of Etawah Crossbred Goat at Different Physiological Stages Fed Elephant Grass and Tofu Byproduct. Journal of Animal Production. Vol 17, No 1 (2015)

Yusha'u, M., Onuorah, F. C. and Murtala, Y. 2009. NVitro Sensitivity Pattern of Some Urinary Tract Isolates to Carica Papaya Extracts. Bayero Journal of Pure and Applied Sciences, 2(2): 75 - 78. 